\title{
Pilgrims to the Eurozone: How far, how fast?
}

\author{
Evžen Kočenda ${ }^{\text {a,b,c,*, }}$, Ali M. Kutan ${ }^{\text {b,d,e,f }}$, Taner M. Yigit ${ }^{\mathrm{g}}$ \\ ${ }^{\text {a } C E R G E-E I, ~ C h a r l e s ~ U n i v e r s i t y ~ a n d ~ t h e ~ A c a d e m y ~ o f ~ S c i e n c e s, ~ P r a g u e, ~ C z e c h ~ R e p u b l i c ~}$ \\ ${ }^{\mathrm{b}}$ The William Davidson Institute (WDI), Michigan, United States \\ ${ }^{\mathrm{c}}$ CEPR, London, United Kingdom \\ ${ }^{\mathrm{d}}$ Southern Illinois University Edwardsville, United States \\ ${ }^{\mathrm{e}}$ The Center for European Integration Studies (ZEI), Bonn, Germany \\ ${ }^{\mathrm{f}}$ The Emerging Markets Group, London, United Kingdom \\ ${ }^{\mathrm{g}}$ Bilkent University, Ankara, Turkey
}

Received 15 January 2006; received in revised form 1 June 2006; accepted 24 July 2006

\begin{abstract}
In our analysis, we re-examine the nominal and real convergence of all recent 10 European Union (EU) members to EU standards. Testing for monetary convergence has significant implications for interim optimal exchange rate and monetary policies before a formal and permanent link to the euro, while real convergence is the ultimate objective of economic integration. Novel features of the paper include broader measures of real convergence in both euro as well as local currencies, an examination of inflation and interest rate convergence with respect to the Maastricht benchmarks, and employment of more appropriate tests of convergence allowing for structural breaks. The results indicate slow but steady per-capita real income convergence towards EU standards. On the other hand, evidence indicates significant strong inflation and interest rate convergence. Policy implications of the paper are also discussed.
\end{abstract}

(C) 2006 Elsevier B.V. All rights reserved.

JEL classification : C23; E42; E61; F02; H60; P50

Keywords: Real and nominal convergence; European Union; Integration; Transition; Eurozone

\section{Introduction and motivation}

In May 2004, 10 new members joined the European Union (EU). ${ }^{1}$ All of these countries must join the Eurozone once they satisfy the Maastricht criteria. Although EU accession leaves new members some freedom to select how to link their national currencies to the euro, policymakers

\footnotetext{
* Corresponding author at: CERGE-EI, Charles University and the Academy of Sciences, Prague, Czech Republic. E-mail address: evzen.kocenda@cerge-ei.cz (E. Kočenda).

${ }^{1}$ Eight of them were Central and Eastern European countries (hereafter the CEE8), namely the Czech Republic, Estonia, Hungary, Latvia, Lithuania, Poland, the Slovak Republic, and Slovenia. The other new members were Cyprus and Malta.
} 
in the new member countries appear to be inclined to adopt the euro sooner rather than later (McKinnon, 1999; Buiter and Grafe, 2002; Buiter, 2004). The sooner the new EU countries complete their restructuring process and become more like the core EU members in terms of a broad range of macroeconomic indicators, the more likely and faster they are to unilaterally adopt the euro (e.g., Salvatore, 2004). This paper quantifies where the new members stand in terms of the nominal convergence process with respect to (a) official Maastricht criteria as well as (b) comparable real convergence performance in the Eurozone. Testing for monetary convergence has significant implications for interim optimal exchange rate and monetary policies before a formal and permanent link to the euro, while real convergence is the ultimate objective of the new member states' economic integration efforts.

We take an innovative and comprehensive approach to the issue of convergence by examining both nominal and real economic convergence for the ten new EU members. We contribute to the related literature in several unique ways. First, in the spirit of the neoclassical growth model, we test the convergence of new member countries' per capita GDP towards the level of the core EU countries to see whether a significant improvement in the standard of living of citizens of the new countries has been achieved. Initially, we start by measuring real convergence in terms of an aggregate output expressed in a common currency (euro) and in local currencies. There are three good reasons for using the common currency approach. First, firms in the new EU economies are selling and will sell more and more in euro markets. As von Hagen and Hofmann (2004) argue, "it is the aggregate euro-area price level that matters for them" (p. 18). Given the large degree of market integration in the euro area, it is more appropriate to use euro-area prices, rather than a national currency, to gauge aggregate demand in the euro area, which, given a production level, directly affects real GDP. In addition, most of the new EU members already have tied their national currencies to the euro. The second reason is political: the CEE8 only recently emerged from the transition and their citizens do not share equal sentiments with respect to monetary subordination because of the fear of an increase in prices after adopting the euro. Hence, finding a faster convergence measured in a common currency relative to the one in the domestic currency would create a stronger argument in favor of entering the EMU sooner rather than later. Finally, finding convergence in both national currencies and the euro would suggest progress towards exchange rate convergence, satisfying another condition of the Maastricht Treaty.

Second, we elaborate on the inflation convergence requirement from the perspective of inflation targeting. Several new EU member states, i.e., the Czech Republic, Hungary, Poland, and Slovakia, have already adopted a regime of inflation targeting as a disinflation tool. Our empirical results allow us to infer whether the new members, at least those that adopted an inflation-targeting regime, are ready to follow an inflation targeting approach that is similar to that of the ECB. Considering convergence towards the benchmark potentially affects the admission process into the Eurozone. For instance, it is frequently argued that the inflation targeting regime is incompatible with an exchange rate band arrangement (see Mishkin, 2004); ERM2 is such an arrangement, and adhering to it is one of the Maastricht conditions. Further, an individual member's inflation rate is likely to affect its entry date to the Eurozone, especially for those with fiscal indiscipline.

Third, we use a novel and what we consider to be the most appropriate methodology to analyze the issue of the "catching up" of the new entrants to the old EU members. Until recently, the cross-sectional tests used in analyzing absolute convergence were criticized for over-rejection of the null hypothesis of no convergence (Bernard and Durlauf, 1996), shifting the emphasis to conditional and stochastic convergence. However, the need to meet the EU criteria for full EMU membership has regenerated interest in absolute convergence. A recent test developed by 
Vogelsang $(1998,1999)$ and applied in the context of Carlino and Mills (1993) by Tomljanovich and Vogelsang (2002) is particularly suitable for analyzing absolute convergence. In addition to the flexibility of this test in being able to derive convergence estimates reliably, it also allows for possible structural breaks, which is critical in drawing correct inferences about convergence. The growing literature ${ }^{2}$ on the presence of structural breaks, especially in emerging economies, further motivates and validates the appropriateness of this methodology. Using this methodology also allows checking the robustness of previous studies' findings of nominal and real convergence.

In assessing real convergence, we use a widely recognized measure, namely real per-capita GDP, instead of industrial production that has been used as a proxy for real convergence in most previous studies. ${ }^{3}$ Real per-capita GDP convergence is measured with respect to two benchmarks: average of the per-capita GDP in (1) the EU core that is represented by Austria, Belgium, France, Germany and the Netherlands; (2) the EU periphery that is represented by Greece, Portugal, and Spain. Further, the real per-capita GDP is measured in euros as well as in a local currency to analyze the impact of exchange rate effects on convergence and to provide inferences on exchange rate convergence.

For nominal convergence, we use benchmarks based on the Maastricht criteria. ${ }^{4}$ We test for monetary convergence, measured in terms of inflation and interest rates. Due to the lack of comparable long-term interest rates for the new EU countries and the short sample available, ${ }^{5}$ we provide only a graphical treatment of the interest rate convergence for 10-year bond data as much as it is available.

In the next section, we provide a review of the literature. Section 3 describes our methodology and data. Empirical results are reported in Section 4. The last section concludes with policy implications of the results.

\section{A brief review of the literature}

The convergence of the new EU members towards the core EU has been studied from two major angles. One strand of the convergence literature is based on the concept of the optimal currency area (for a recent survey, see Horvath, 2003; Fidrmuc and Korhonen, 2004a). The seminal paper by Bayoumi and Eichengreen (1993) forms the methodological basis of much of the work on this issue. These authors test whether EU members displayed a sufficient correlation of their supply (real) and demand (monetary) shocks over the period 1960-1988. Many follow-up studies report considerably more business cycle convergence to EU standards than found in Bayoumi and Eichengreen (1993) (Boone and Maurel, 1998, 1999; Korhonen and Fidrmuc,

\footnotetext{
${ }^{2}$ Dibooglu and Kutan (2001), Fidrmuc and Tichit (2004), and Kočenda (2005), among others.

${ }^{3}$ Real GDP per capita is a better measure of living standards because industrial production represents a narrow measure of economic activity and changes in industrial production are more cyclical than GDP. Kočenda (2001), Kutan and Yigit (2004, 2005), and Brada et al. (2005) use industrial production to test for real convergence.

${ }^{4}$ The Maastricht criteria require that: the national central bank of the country should be independent, the country's currency should have participated without stress in the Exchange Rate Mechanism for at least 2 years, the country's inflation rate should have been below a reference value given by a range of 1.5 percentage points above that of the best three inflation performers, the country's long-term interest rate should have been within two percentage points of that of the three best inflation performers, the ratio of the budget deficit to gross domestic product (GDP) should not exceed $3 \%$, and the country's debt-to-GDP ratio should not exceed $60 \%$. In our analysis we use two monetary and two fiscal criteria and leave the question of exchange rate stability and central bank independence aside.

${ }^{5}$ For many new EU members comparable long-term instruments (10-year maturity) exist only from 2000.
} 
2001; Fidrmuc and Korhonen, 2004b). However, more recent studies display conflicting results. Babetskii et al. (2004) report significant convergence of demand shocks, but divergence of supply shocks. Horvath and Rátfai (2004) show that shocks among the core and candidate EU countries tend to be uncorrelated. Sayek and Selover (2002) find that EU-wide shocks have a relatively small influence on business cycles in Turkey.

A second strand of the literature focuses on the nominal and real convergence of the candidate countries and the existing EU members. Brada and Kutan (2001) examine monetary-policy convergence, while Janáčková (2000), Richards and Tersman (1996), and Backé et al. (2003) investigate price-level convergence between the EU and the transition-economy candidates. These studies find weak monetary- and price-level convergence. Kočenda (2001), Kutan and Yigit (2004, 2005), and Brada et al. (2005) study not only nominal level convergence, but also real convergence. While Kočenda (2001) reports considerable real and monetary convergence, Kutan and Yigit (2004) find less convergence than Kočenda does. Kutan and Yigit (2005) observe that price and monetary convergence of the new EU members to the core EU standards is quite idiosyncratic. Brada et al. (2005) conclude that a peg to the euro soon after accession is feasible for the East European countries.

Overall, the results on nominal and real convergence are mixed. Besides different sample periods and country coverage, the divergences in results appear to be driven by different methodologies. In addition, structural breaks in series may further distort the findings. We already mentioned that there exists empirical evidence of structural breaks in many economic indicators portraying the landscape of the transition and pre-accession process in the CEE countries, not to mention the fact that the transition alone represented a massive structural shift by definition. Hence, a comprehensive study based on a longer sample period, supplemented by structural break tests, is necessary.

\section{Methodology and data}

\subsection{Convergence methodology}

The analysis of convergence has been an active as well as challenging field of interest since the late 1980s. ${ }^{6}$ Numerous methods have been used to analyze different measures of convergence, namely absolute or conditional $\beta$-convergence, sigma convergence, and stochastic convergence. While the former two types analyzed the issue of catching up, the latter and more recent focused on the synchronization of shocks and cross-sectional units moving together in time. The enlargement of the EU has refocused interest in the issue of the "catching up" of the new entrants to the core EU members. Cross-sectional tests mostly used to analyze $\beta$-convergence were criticized on the grounds of over-rejecting the null hypothesis of no convergence (Quah, 1996; Bernard and Durlauf, 1996). These criticisms pushed researchers to apply time series (or panel data) methodologies to introduce a second dimension to $\beta$-convergence.

A new test by Vogelsang $(1998,1999)$ deals with the $\beta$-convergence issue by relying on timeseries methodology. Following this literature, we consider a simple model of convergence towards a benchmark as

$$
y_{t}=\mu+\delta t+u_{t}
$$

\footnotetext{
${ }^{6}$ For recent discussions, see Taylor (1999) and de la Fuente (2002).
} 
where $y_{t}$ is the difference of the natural logarithm of a variable minus a benchmark, in our case for example, the per-capita GDP of country $i$ minus the European benchmark at time $t$ would be the $y_{t}$ variable, while $\mu$ is an intercept to capture the initial level of the deviation, $t$ is a deterministic time trend, and $u_{t}$ is the residual term. In such a set-up, $\beta$-convergence requires that for countries where $\mu$ is initially significantly negative, so the country is lagging behind, the trend coefficient $\delta$ should be positive and statistically significant. Carlino and Mills (1993) developed this test with a very restricted form of serial correlation for the residual term, namely AR(2). Vogelsang (1998) extended the analysis of this specification to $u_{t}$ with an unknown form of serial correlation by allowing a span of stationary and non-stationary serial correlation specifications for the error term ranging from integration of order zero, $I(0)$, to of order one, $I(1)$. Since the possibility of no convergence implies nonstationarity of the error terms, one can draw a false inference on the trend coefficient when the errors are assumed to be stationary AR(2). ${ }^{7}$ Vogelsang's (1998) methodology, in the spirit of Eq. (1), considers the following Partial Sums with $J$ correction (PSW) test statistic that helps to alleviate the above problems. ${ }^{8}$ It is defined as:

$$
\mathrm{PSW}_{T}=\frac{T^{-1}(R \hat{\beta}-r)^{\prime}\left[R\left(X^{\prime} X\right)^{-1} R^{\prime}\right]^{-1}(R \hat{\beta}-r)}{\left(100 T^{-1} s_{z}^{2} \exp \left(b J_{T}(m)\right)\right)}
$$

where $X$ and $\beta$ consist of [1 $\quad t]$ and $\left[\begin{array}{ll}\mu & \delta\end{array}\right]$ respectively, $s_{z}^{2}$ is the standard deviation of the partial cumulated sum of $y_{t}$, and $J_{T}$ is the Park and Choi (1988) unit root test statistic obtained from the following regression

$$
\begin{aligned}
& y_{t}=X_{t} \beta+\sum_{i=2}^{m} c_{i} t^{i}+u_{t} \\
& J_{T}(m)=\left(\mathrm{RSS}_{y}-\mathrm{RSS}_{J}\right) / \mathrm{RSS}_{J}
\end{aligned}
$$

In other words, $J_{T}$ is the Wald statistic that tests the joint hypothesis of $c_{2}=c_{3}=\cdots=c_{m}=0$. In Monte Carlo simulations, Vogelsang (1998) finds the values of $b$ and $m$ for which the above tests would be comparable and valid for every type of serial correlation form, including unit roots.

Despite the great flexibility of these tests in deriving the mean and trend coefficient estimates in time series with varying stationarity properties, one needs to be careful in using this methodology in the analysis of post-transition economies. The reason stems from the volatile nature of these economies and the presence of structural shifts that are documented in the empirical literature. The problem of structural breaks during the transition process is given serious empirical consideration in Fidrmuc and Tichit (2004), who provide evidence of significant breaks for macroeconomic data. They argue that empirical analyses of transition economies must account for the possibility of structural changes, otherwise inferences are misleading. However, only a few papers consider the structural breaks on transition issues (see for example Dibooglu and Kutan, 2001; Kočenda, 2005).

We obtain robust results by using Vogelsang's (1999) methodology that allows for structural breaks in the modification of the statistics by including the possibility of shifts in the trend function. The test has been designed in two versions: one with predetermined breaks and the other with endogenous break selection. We favor the latter one. First, we estimate the break date

\footnotetext{
${ }^{7}$ When $u_{t}$ is $I(1)$, the estimate of $\beta$ obtained from the above regression is not related to the true trend, and information on $\beta$ must be obtained from the estimate of the intercept in the autoregressive representation of $y_{t}$.

${ }^{8}$ See Vogelsang (1998) for further test statistics and a deeper elaboration of the tests.
} 
Table 1

Timing of the EU admission process

\begin{tabular}{llll}
\hline & Application submitted & Admission negotiations & End \\
\cline { 3 - 3 } & & Beginning & December 13, 2002 \\
\hline Czech Republic & January 17, 1996 & March 31, 1998 & December 13, 2002 \\
Cyprus & July 3, 1990 & March 31, 1998 & December 13, 2002 \\
Estonia & November 24, 1995 & March 31, 1998 & December 13, 2002 \\
Hungary & March 31, 1994 & March 31, 1998 & December 13, 2002 \\
Latvia & October 13, 1995 & October 13, 1999 & December 13, 2002 \\
Lithuania & December 8, 1995 & October 13, 1999 & December 13, 2002 \\
Malta & July 16, 1990 & October 13, 1999 & December 13, 2002 \\
Poland & April 5, 1994 & March 31, 1998 & December 13, 2002 \\
Slovakia & June 27, 1995 & October 13, 1999 & December 13, 2002 \\
Slovenia & June 10, 1996 & March 31, 1998 & \\
\hline Source: Eunber & & &
\end{tabular}

Source: European Commission.

using the optimal tests of Andrews and Ploberger (1994). Then, using the estimated break date, normalized critical values are obtained using the following altered version of Eq. (1)

$$
y_{t}=\mu_{1} \mathrm{DU}_{1 t}+\mu_{2} \mathrm{DU}_{2 t}+\delta_{1} \mathrm{DT}_{1 t}+\delta_{2} \mathrm{DT}_{2 t}+u_{t}
$$

where $\mathrm{DU}_{1 t}=1$ if $t \leq T_{b}$ (the break date) and zero otherwise, $\mathrm{DU}_{2 t}=1$ if $t>T_{b}$ and zero otherwise, $\mathrm{DT}_{1 t}=t$ if $t \leq T_{b}$ and zero otherwise, and finally $\mathrm{DT}_{2 t}=t-T_{b}$ if $t>T_{b}$ and zero otherwise. Analysis of Vogelsang (1999), using data from Maddison (1991), and a later application by Tomljanovich and Vogelsang $(2002)^{9}$ that focuses mainly on convergence issues, provide interesting exploitations of this methodology.

\subsection{Data}

We analyze real convergence of the CEE8, Cyprus, and Malta, using real GDP per-capita figures, both in local currency and euros, to draw implications as to how long it would take for these new EU countries to catch up to the standards of their Western counterparts. For this purpose, we examine two benchmarks: the core of the EU, represented by the average of Austria, Belgium, France, Germany and the Netherlands, and the periphery represented by average values from Greece, Portugal and Spain.

We also analyze performance of the new EU countries in satisfying the subset of convergence criteria of the Maastricht Treaty. For monetary convergence, we use data on inflation (based on the twelve month average of the year-on-year inflation rates as set out in the Treaty and practiced by the ECB) and interest rates (10-year government bond yield). Specifically, for our inflation measure, we use the lowest three (non-negative) inflation rates of the EU15 plus $1.5 \%$, and for interest rates we examine the same three countries' average 10-year government bond yield plus $2 \% .^{10}$

We use quarterly data from 1995:1 through 2005:4 for GDP. For inflation and interest rates we use monthly data, starting from 1996:01 for inflation and 2000:01 for bond yields, and ending in 2005:12. This time span was chosen because: (1) official EU membership applications started in

\footnotetext{
${ }^{9}$ We are grateful to the authors for providing us with the Gauss routine used in this paper.

${ }^{10}$ For both inflation and interest rate benchmarks we use data from the EU15 since the 10 new members joined the EU only on May 1, 2004.
} 


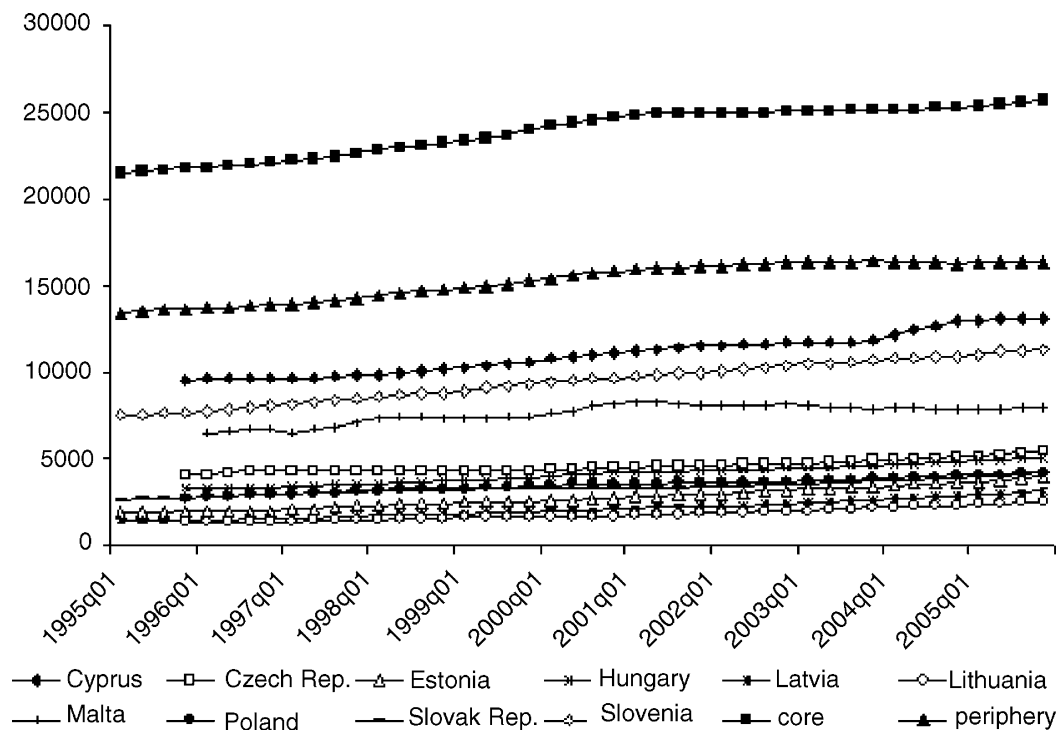

Fig. 1. Per-capita GDP in Euros.

1995 and (2) EuroStat began using the harmonized time series on prices and other macroeconomic variables at that time. In addition, the post-1995 period excludes the major transition-related shocks observed in the early 1990s. Table 1 documents the major milestones in the pre-accession process: the date when an application to join the EU was submitted and the beginning and end of the admission negotiations. The data are obtained primarily from the EuroStat database and checked for consistency against the International Financial Statistics of the IMF. In case of missing or incomplete observations, data are gathered from the individual central banks and finance ministries. Seasonality in GDP data is eliminated by annualizing the quarterly GDP $\left(g_{t}=\sum_{s=1}^{4} \operatorname{GDP}_{t-s}\right)$, while inflation rates $\left(\pi_{t}\right)$ are average rates of inflation based on a twelve month average of the year-on-year rates. ${ }^{11}$ Real GDP per capita data in euros are given in Fig. 1. We should note at this point that the serial correlation generated by the methodology used for de-seasonalizing the data is of little concern here since the Vogelsang test is able to handle broad forms of serial correlation. Finally, we create a real GDP, per-capita index, using 1996 as the base year to be able to compare real GDP per capita data measured in different local currencies to each other (see Fig. 2). Since the recent ten members should grow faster in real terms to "catch up" with the benchmarks, observing divergence in the indexes away from the benchmark would indicate convergence.

\section{Estimation and results}

The results are displayed in Tables 2 through 3. They display the coefficient estimates along with the Partial Sums with $J$ correction test statistics given by the specification in Eq. (2). ${ }^{12}$

\footnotetext{
${ }^{11}$ Our methodology helps alleviate the potential problem of the error term in de-seasonalized variables being polluted by leading and lagged errors. The error term will not be correlated with the explanatory variables since we only have deterministic regressors (the mean and the trend).

12 The results for other statistics by Vogelsang (1999) are available from the authors upon request.
} 


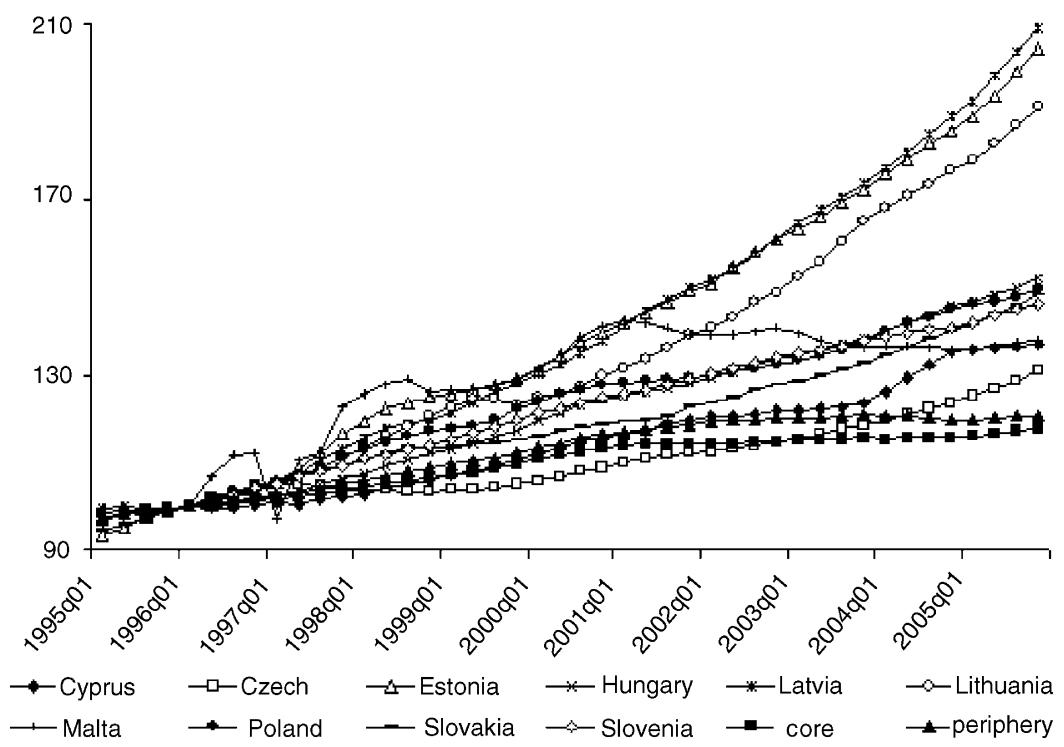

Fig. 2. Real per-capita GDP index (1996=100 in local currency).

The last column in each table contains the estimated break date using the maximum Wald statistic. Following the theoretical grounds of the methodology employed, we apply a $10 \%$ trimming from each end of the sample since the break dates close to the endpoints are unreliable and should mostly be disregarded. We display the asymptotic critical values for the endogenous break option of the PSW at the bottom rows of each table. When interpreting results, readers should note that positive trend coefficients represent improvements of position in comparison to the Union. For instance, while a positive trend coefficient shows new members' GDP per capita approaching EU levels, a positive trend in inflation will indicate a decline in inflation toward the best EU performance. In short, a positive trend coefficient is always good. We supplement this brief explanation at the bottom of each table by indicating the dependent variable and providing a brief guideline to interpret the results easily.

\subsection{Real convergence}

We report the results of real convergence measured by the developments of real per-capita GDP in Tables 2a to $2 \mathrm{~d}$. Significance levels reported in the tables are for the null hypothesis that the difference between the per-capita GDP of each new member and that of the core or the periphery average is zero or that the disparity is not deterministically changing. As described earlier in Section 3.2, we use the average of the GDP per-capita of Austria, Belgium, France, Germany and the Netherlands as the benchmark for the EU core. The average of Greece, Portugal and Spain is the proxy for the EU periphery since these countries are closer to the new EU member countries in many respects and such a comparison is frequent in the literature. Thus, our dependent variable in Tables $2 a$ to $2 b$ is the difference between per-capita GDP (in euros) of each new member and the core or the periphery average. Due to a lower initial level of per-capita GDP in the new EU members, such a difference is inevitably a negative number and convergence would be reflected in a positive and significant trend (faster growth than the benchmark). Further, 
Table 2a

Log per-capita GDP convergence in Euros (to the EU15 core level)

\begin{tabular}{llllll}
\hline Countries & \multicolumn{2}{l}{ PSW test with endogenous break selection (regression of $y_{t}$ with $J_{T}$ correction) } & Break date \\
\cline { 2 - 5 } & \multicolumn{1}{l}{$\mu_{1}$} & $\delta_{1}$ & $\mu_{2}$ & $\delta_{2}$ \\
\hline Cyprus & $-0.83^{* *}(-40.74)$ & $0.00(0.67)$ & $-0.81^{* *}(-36.10)$ & $0.01^{* *}(4.06)$ & $2000 \mathrm{Q} 4$ \\
Czech Republic & $-1.64^{* *}(-63.73)$ & $0.00(-1.49)$ & $-1.71^{* *}(-57.31)$ & $0.01^{* *}(2.86)$ & $2001 \mathrm{Q} 1$ \\
Estonia & $-2.47^{* *}(-183.65)$ & $0.01^{* *}(11.44)$ & $-2.28^{* *}(-196.16)$ & $0.02^{* *}(21.08)$ & $1999 \mathrm{Q} 3$ \\
Hungary & $-1.90^{* *}(-169.19)$ & $0.00^{* *}(6.29)$ & $-1.78^{* *}(-130.29)$ & $0.01^{* *}(7.26)$ & $2001 \mathrm{Q} 2$ \\
Latvia & $-2.70^{* *}(-179.47)$ & $0.01^{* *}(8.38)$ & $-2.50^{* *}(-158.00)$ & $0.02^{* *}(14.77)$ & $2000 \mathrm{Q} 3$ \\
Lithuania & $-2.83^{* *}(-185.80)$ & $0.01^{* *}(7.22)$ & $-2.72^{* *}(-187.38)$ & $0.02^{* *}(16.94)$ & $2000 \mathrm{Q} 1$ \\
Malta & $-1.22^{* *}(-72.78)$ & $0.00^{* *}(2.93)$ & $-1.10^{* *}(-65.64)$ & $0.00^{* *}(-2.65)$ & $2000 \mathrm{Q} 2$ \\
Poland & $-2.08^{* *}(-152.40)$ & $0.01^{* *}(7.01)$ & $-1.96^{* *}(-130.36)$ & $0.01^{* * *}(5.89)$ & $2000 \mathrm{Q} 4$ \\
Slovak Republic & $-2.08^{* *}(-109.27)$ & $0.01^{* *}(3.27)$ & $-2.05^{* *}(-118.64)$ & $0.01^{* *}(7.31)$ & $1999 \mathrm{Q} 4$ \\
Slovenia & $-1.06^{* *}(-145.79)$ & $0.01^{* *}(9.89)$ & $-0.95^{* *}(-138.36)$ & $0.01^{* *}(12.46)$ & $2000 \mathrm{Q} 1$ \\
Critical value at 95\% & 1.51 & 1.88 & 1.92 & 1.81 & 1.54 \\
Critical value at 90\% & 1.21 & 1.58 & & 1.65 & \\
\hline
\end{tabular}

Note: each number represents the natural log of thousands of Euros. The dependent variable is the per-capita GDP level in country $i$ minus the core (or periphery) output per capita. Therefore, a negative mean coefficient, $\mu$, indicates lower mean GDP per capita than the benchmark, and a positive trend, $\delta$, indicates a narrowing down of this difference. Significance is reported by comparing the statistics in the parentheses to the critical values in the bottom two rows of the table.

** Indicates $95 \%$ significance.

Table $2 b$

Log per-capita GDP convergence in Euros (to the EU15 periphery level)

\begin{tabular}{|c|c|c|c|c|c|}
\hline \multirow[t]{2}{*}{ Countries } & \multicolumn{4}{|c|}{ PSW test with endogenous break selection (regression of $y_{t}$ with $J_{T}$ correction) } & \multirow[t]{2}{*}{ Break date } \\
\hline & $\mu_{1}$ & $\delta_{1}$ & $\mu_{2}$ & $\delta_{2}$ & \\
\hline Cyprus & $-0.38^{* *}(-17.11)$ & $0.00(1.10)$ & $-0.29^{* *}(-5.79)$ & $0.01(1.10)$ & 2003Q4 \\
\hline Czech Republic & $-1.18^{* *}(-44.51)$ & $0.003^{* *}(-1.94)$ & $-1.27^{* * *}(-35.58)$ & $0.01^{* *}(2.53)$ & 2001Q4 \\
\hline Estonia & $-1.98^{* *}(-73.64)$ & $0.01^{* *}(6.72)$ & $-1.68^{* * *}(-41.44)$ & $0.02^{* *}(4.02)$ & $2002 Q 2$ \\
\hline Hungary & $-1.43^{* *}(-133.05)$ & $0.004^{* *}(6.17)$ & $-1.32^{* *}(-81.57)$ & $0.01^{* *}(5.72)$ & 2002Q2 \\
\hline Latvia & $-2.24^{* *}(-135.78)$ & $0.01^{* *}(8.07)$ & $-2.02^{* * *}(-100.58)$ & $0.02^{* *}(10.57)$ & 2001Q2 \\
\hline Lithuania & $-2.36^{* *}(-103.47)$ & $0.01^{* *}(4.71)$ & $-2.18^{* *}(-70.98)$ & $0.02^{* *}(6.30)$ & 2001Q4 \\
\hline Malta & $-0.76^{* *}(-49.83)$ & $0.003^{* *}(3.56)$ & $-0.69^{* *}(-35.66)$ & $0.00(-1.18)$ & 2001Q3 \\
\hline Poland & $-1.60^{* *}(-93.74)$ & $0.01^{* *}(4.78)$ & $-1.52^{* * *}(-73.08)$ & $0.01^{* *}(4.51)$ & 2001Q2 \\
\hline Slovak Republic & $-1.60^{* * *}(-57.80)$ & $0.00(1.43)$ & $-1.60^{* * *}(-55.08)$ & $0.01^{* *}(4.29)$ & 2000Q3 \\
\hline Slovenia & $-0.58^{* *}(-77.59)$ & $0.004^{* *}(8.04)$ & $-0.51^{* *}(-64.28)$ & $0.01^{* *}(10.23)$ & 2000Q3 \\
\hline Critical value at $95 \%$ & 1.51 & 1.88 & 1.92 & 1.81 & \\
\hline Critical value at $90 \%$ & 1.21 & 1.58 & 1.65 & 1.54 & \\
\hline
\end{tabular}

Note: Each number represents the natural log of thousands of Euros. The dependent variable is the per-capita GDP level in country $i$ minus the core (or periphery) output per capita. Therefore, a negative mean coefficient, $\mu$, indicates lower mean GDP per capita than the benchmark, and a positive trend, $\delta$, indicates a narrowing down of this difference. Significance is reported by comparing the statistics in the parentheses to the critical values in the bottom two rows of the table.

** Indicates $95 \%$ significance. 
Table 2c

Per-capita GDP convergence in National Currency (to the EU15 core level)

\begin{tabular}{lccccc}
\hline Countries & \multicolumn{2}{l}{ PSW test with endogenous break selection (regression of $y_{t}$ with $J_{T}$ correction) } & Break date \\
\cline { 2 - 5 } & \multicolumn{1}{l}{$\mu_{1}$} & $\delta_{1}$ & $\mu_{2}$ & $\delta_{2}$ \\
\hline Cyprus & $-3.15(-1.03)$ & $0.27^{* *}(1.89)$ & $12.28^{*}(1.75)$ & $1.11(0.80)$ & $2003 \mathrm{Q} 4$ \\
Czech Republic & $2.37(0.86)$ & $-0.28(-1.54)$ & $-5.62^{*}(-1.76)$ & $0.90^{* *}(3.23)$ & $2001 \mathrm{Q} 1$ \\
Estonia & $-6.40^{* *}(-2.93)$ & $1.39^{* *}(10.23)$ & $30.07^{* *}(10.75)$ & $3.15^{* *}(11.53)$ & $2001 \mathrm{Q} 3$ \\
Hungary & $-2.82^{* *}(-1.80)$ & $0.53^{* *}(5.26)$ & $10.78^{* *}(5.66)$ & $1.31^{* *}(7.43)$ & $2001 \mathrm{Q} 2$ \\
Latvia & $-4.25^{* *}(-1.61)$ & $1.13^{* *}(6.08)$ & $21.27^{* *}(7.29)$ & $3.28^{* *}(13.48)$ & $2000 \mathrm{Q} 4$ \\
Lithuania & $-3.33^{*}(-1.49)$ & $0.89^{* *}(6.38)$ & $19.95^{* *}(6.96)$ & $3.13^{* *}(11.20)$ & $2001 \mathrm{Q} 3$ \\
Malta & $-1.65(-0.19)$ & $0.90(0.72)$ & $22.60^{* *}(4.82)$ & $-0.01(-0.06)$ & $1997 \mathrm{Q} 3$ \\
Poland & $-2.75^{* *}(-2.10)$ & $0.76^{* *}(8.57)$ & $11.23^{* *}(7.39)$ & $1.09^{* *}(8.21)$ & $2001 \mathrm{Q} 1$ \\
Slovak Republic & $-1.41(-0.52)$ & $0.42^{* *}(2.15)$ & $1.53(0.54)$ & $1.32^{* *}(5.87)$ & $2000 \mathrm{Q} 3$ \\
Slovenia & $-2.46^{* *}(-4.12)$ & $0.64^{* *}(13.37)$ & $8.96^{* *}(15.71)$ & $0.87^{* *}(20.95)$ & $2000 \mathrm{Q} 1$ \\
Critical value at 95\% & 1.51 & 1.88 & 1.92 & 1.81 & 1.54 \\
Critical value at 90\% & 1.21 & 1.58 & & 1.65 & \\
\hline
\end{tabular}

Note: All real GDP figures have been equalized at the base year 1996 (beginning period for Maltese data). The dependent variable is the per-capita GDP level in country $i$ minus benchmark output per capita. Therefore, convergence would be reflected with a significant positive trend. Positive mean levels (e.g., post-break) means, $\mu$, that new members have grown more since 1996, and positive trends, $\delta$, mean that they continue to do so. Significance is reported by comparing the statistics in the parentheses to the critical values in the bottom two rows of the table.

* Indicates $90 \%$ significance.

** Indicates $95 \%$ significance.

Tables $2 \mathrm{c}$ and $2 \mathrm{~d}$ display the estimations using real per-capita GDP in the local currency. To avoid local currency incompatibilities, we equalize the per-capita GDP levels at an arbitrarily chosen base year $(1996: 1=100)$. Hence, we expect all countries to start from the same level (a zero mean) and have a faster growth rate than the benchmark countries (positive trend).

The results in Tables $2 \mathrm{a}$ and $2 \mathrm{~b}$ confirm that all new EU members start below the per-capita GDP level of the core and the periphery in euros, and the difference is understandably larger with respect to the core. The endogenously detected break dates are all around the year 2000, in the middle of the accession talks as sufficient progress was made toward the outcome of the negotiations. ${ }^{13}$ Since the GDP per capita levels of the new members are below those of the core and the periphery (indicated by the negative $\mu$ coefficients), statistically significant trends imply convergence toward the core or the periphery. One notes that during the pre-break or post-break period, the trends are positive for most countries. We find evidence that strong convergence is taking place towards the core (Table 2a) picking up speed, after the break, in Cyprus, the Czech Republic, Hungary and the Baltic countries. The situation is similar for the convergence to the periphery (Table $2 \mathrm{~b}$ ); the Baltic countries still perform strongly while the Czech Republic and Hungary experience a slowdown after 2000 in their catch-up speed. This is likely caused by the strong growth performance of the periphery countries when compared to the core.

In short, our results suggest that most of the new EU members have a higher per-capita GDP growth rate than do the EU15 countries, and the difference in growth rates will have to continue for decades for full convergence to occur. This phenomenon can be illustrated on a real-life

\footnotetext{
${ }^{13}$ Certainly, economic developments, including recessions and recoveries, in the core and periphery might have affected the outcome of the break tests. We leave the issue of identifying the exact sources of structural break dates to future research.
} 
Table 2d

Per-capita GDP convergence in National Currency (to the EU15 periphery level)

\begin{tabular}{|c|c|c|c|c|c|}
\hline \multirow[t]{2}{*}{ Countries } & \multicolumn{4}{|c|}{ PSW test with endogenous break selection (regression of $y_{t}$ with $J_{T}$ correction) } & \multirow[t]{2}{*}{ Break date } \\
\hline & $\mu_{1}$ & $\delta_{1}$ & $\mu_{2}$ & $\delta_{2}$ & \\
\hline Cyprus & $-2.31(-0.82)$ & $0.09(0.70)$ & $6.73(1.05)$ & $1.44(1.13)$ & 2003Q4 \\
\hline Czech Republic & $2.32(0.85)$ & $-0.37^{* *}(-2.35)$ & $-9.41^{* *}(-2.41)$ & $1.21^{* *}(2.82)$ & 2002Q1 \\
\hline Estonia & $-5.74^{* * *}(-2.88)$ & $1.25^{* *}(10.74)$ & $29.62^{* *}(10.44)$ & $3.39^{* *}(10.85)$ & 2002Q1 \\
\hline Hungary & $-2.45^{* *}(-1.36)$ & $0.40^{* *}(3.80)$ & $8.27^{* * *}(3.22)$ & $1.52^{* * *}(5.36)$ & 2002Q1 \\
\hline Latvia & $-3.97(-1.18)$ & $1.02^{* *}(4.71)$ & $21.13^{* *}(5.17)$ & $3.47^{* *}(9.19)$ & 2001Q2 \\
\hline Lithuania & $-2.91^{*}(-1.50)$ & $0.75^{* *}(6.44)$ & $16.71^{* *}(6.38)$ & $3.32^{* * *}(12.26)$ & 2001Q4 \\
\hline Malta & $-1.29(-0.18)$ & $0.78(0.72)$ & $20.66^{* *}(5.10)$ & $-0.11(-0.54)$ & 1997Q3 \\
\hline Poland & $-1.79^{*}(-1.25)$ & $0.56^{* *}(6.26)$ & $6.77^{* *}(3.70)$ & $1.29^{* * *}(7.21)$ & 2001Q3 \\
\hline Slovak Republic & $0.32(0.10)$ & $0.15(0.88)$ & $4.29(0.85)$ & $1.75^{* *}(2.73)$ & 2002Q3 \\
\hline Slovenia & $-1.09^{* * *}(-2.04)$ & $0.41^{* * *}(13.20)$ & $10.50^{* * *}(13.82)$ & $0.98^{* *}(11.76)$ & 2002Q1 \\
\hline Critical value at $95 \%$ & 1.51 & 1.88 & 1.92 & 1.81 & \\
\hline Critical value at $90 \%$ & 1.21 & 1.58 & 1.65 & 1.54 & \\
\hline
\end{tabular}

Note: All real GDP figures have been equalized at the base year 1996 (beginning period for Maltese data). The dependent variable is the per-capita GDP level in country $i$ minus benchmark output per capita. Therefore, convergence would be reflected with a significant positive trend. Positive mean levels (e.g., post-break) means, $\mu$, that new members have grown more since 1996, and positive trends, $\delta$, mean that they continue to do so. Significance is reported by comparing the statistics in the parentheses to the critical values in the bottom two rows of the table.

* Indicates $90 \%$ significance.

*** Indicates $95 \%$ significance.

example: a simple linear approximation shows that a per-capita GDP difference of, say, 18,000 euros between a "rich" and a "poor" EU country will be closed in about 80 years if the poor country per-capita GDP grows at $5 \%$ and the rich country grows at a constant rate of $2 \%$. Using a different set of assumptions and methodology, Fischer et al. (1998, see Table 11) claim that the time needed to close the per-capita GDP gap in accession countries and other transition economies is between 17 and 75 years with an average of 31 years.

Tables $2 \mathrm{c}$ and $2 \mathrm{~d}$ report the results when the per-capita real GDP is measured in local currency. Similar to the euro-based results, we find negative intercept coefficients, indicating a lower initial level of GDP in the new EU members. However, the positive trend coefficient implies (except for Malta and the Czech Republic in the late 1990s) convergence during both pre-break and postbreak periods both towards the core and the periphery. The positive post-break mean (except for Slovak Republic) is also in accord with the observed development. Since we scale nominal values in various currencies and observe a higher growth rate in new EU members, we essentially look for divergence in such a case (see again Fig. 2). Divergence should be understood in a positive sense, however. This result basically means that all countries, including the core, start from the same point $(1996=100)$ and begin growing. Those who grow faster, the new EU members, will naturally have a higher trend value than the core or the periphery. These findings in Tables $2 \mathrm{c}$ and $2 \mathrm{~d}$ look quite encouraging. A summary of all four tables show that the Baltic countries progress quite fast both in euros and local currency to the EU standards while countries like the Czech Republic, Poland and especially Malta tend to slow down their progress. These results suggest that exchange rate convergence is also achieved for the Baltic countries, while the currencies of the other countries have not been as stable against the euro. The Baltic countries seem to be ready to peg their currencies officially to the euro. 
Table 3

Inflation convergence (to benchmark = lowest 3 non-negative inflation rates plus $1.5 \%$ )

\begin{tabular}{lccccc}
\hline Countries & \multicolumn{2}{l}{ PSW test with endogenous break selection (regression of $y_{t}$ with $J_{T}$ correction) } & Break date \\
\cline { 2 - 5 } & \multicolumn{1}{c}{$\mu_{1}$} & $\delta_{1}$ & $\mu_{2}$ & $\delta_{2}$ & \\
\hline Cyprus & $-0.59(-0.43)$ & $0.02(0.49)$ & $-1.11(-1.04)$ & $0.02(0.93)$ & $1999 \mathrm{M} 11$ \\
Czech Republic & $-6.08^{* *}(-2.23)$ & $-0.03(-0.21)$ & $-0.70(-0.40)$ & $0.02(0.66)$ & $1998 \mathrm{M} 12$ \\
Estonia & $-24.54^{* *}(-2.94)$ & $1.10(1.05)$ & $-5.21^{* *}(-1.92)$ & $0.05(1.28)$ & $1997 \mathrm{M} 1$ \\
Hungary & $-23.45^{* *}(-7.79)$ & $0.38^{* *}(2.50)$ & $-8.64^{* *}(-4.74)$ & $0.09^{* *}(2.70)$ & $1998 \mathrm{M} 10$ \\
Latvia & $-9.34^{* *}(-4.79)$ & $0.20^{* *}(3.43)$ & $2.24(1.23)$ & $-0.11^{* *}(-2.38)$ & $2000 \mathrm{M} 10$ \\
Lithuania & $-33.40^{* *}(-4.34)$ & $1.67^{* *}(2.47)$ & $-1.08(-0.34)$ & $0.03(0.65)$ & $1997 \mathrm{M} 8$ \\
Malta & $-2.07^{* *}(-4.34)$ & $0.03^{* *}(2.05)$ & $0.78^{*}(1.75)$ & $-0.02(-1.47)$ & $2000 \mathrm{M} 10$ \\
Poland & $-15.90^{* *}(-10.80)$ & $0.20^{* *}(7.68)$ & $-2.48(-0.87)$ & $0.16(0.90)$ & $2004 \mathrm{M} 1$ \\
Slovak Republic & $-0.67(-0.19)$ & $-0.19^{*}(-1.71)$ & $-4.89(-1.59)$ & $0.04(0.57)$ & $2000 \mathrm{M} 6$ \\
Slovenia & $-7.54^{* *}(-13.22)$ & $0.07^{* *}(3.49)$ & $-7.36^{* *}(-15.78)$ & $0.11^{* *}(10.20)$ & $2000 \mathrm{M} 2$ \\
Critical value at 95\% & 1.51 & 1.88 & 1.92 & 1.81 & 1.54 \\
Critical value at 90\% & 1.21 & 1.58 & 1.65 & \\
\hline
\end{tabular}

Note: The dependent variable is the Maastricht benchmark inflation level minus the inflation in country $i$. Therefore, a negative mean will indicate higher inflation levels than the benchmark, and a positive coefficient indicates an improvement or narrowing of this gap. Significance is reported by comparing the statistics in the parentheses to the critical values in the bottom two rows of the table.

* Indicates $90 \%$ significance.

** Indicates $95 \%$ significance.

\subsection{Nominal-monetary convergence}

According to the Maastricht Treaty criterion of price stability, "a Member State has a price performance that is sustainable and an average rate of inflation, observed over a period of one year before the examination that does not exceed by more than 1.5 percentage points that of the three best performing Member States in terms of price stability" (Art. 109j(1) of the EC Treaty and the respective protocol, Art. 1; see The Treaty (1999) for additional details on other criteria). To construct the benchmark, the common practice is to use an arithmetic average of the three lowest (non-negative) inflation rates over the period plus $1.5 \%$. This is the approach common for both the European Commission and the European Central Bank. ${ }^{14}$

Inflation convergence towards the Maastricht benchmark, the lowest three (non-negative) inflation rates plus $1.5 \%$, is clearly observed for most of the new member countries (Table 3). In general, new EU countries start with a much higher inflation rate and reduce it over time (Fig. 3). A significant finding is a very fast disinflation rate at the beginning of our sample period, especially for Estonia, Hungary, Lithuania, and the Czech Republic. The large negative values

\footnotetext{
${ }^{14}$ It should be noted that the concept of the "outlier" was already included in earlier convergence reports. It does not imply any mechanical approach to the exclusion of certain inflation rates, but it was introduced in the 1998 EMI (European Monetary Institute) Convergence Report to appropriately deal with potential significant distortions in individual countries' inflation developments. Yet another benchmark is possible if the "three best-performing Member States in terms of price stability" are considered as those nearest to the ECB's inflation objective, which is inflation rate close but below $2 \%$. In our analysis, we concentrate on the official definition of the benchmark. Further, Buiter and Grafe (2002) suggest interpreting inflation criteria in terms of only the inflation rate of traded goods prices due to BalassaSamuelson effects. This approach would require a change in the Maastricht Treaty or derogation, and it is therefore beyond the scope of this paper. For an assessment of the Balassa-Samuelson effect in the Central and Eastern Europe, see Égert et al. (2003).
} 


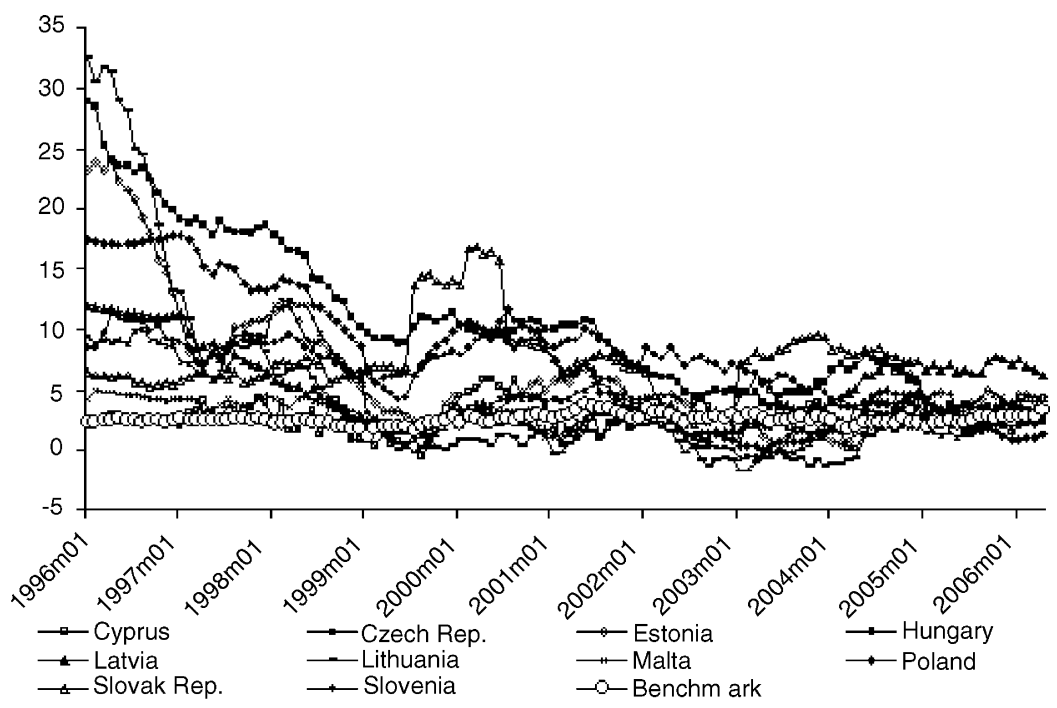

Fig. 3. Inflation convergence to benchmark.

are indicative not only of inflation levels above the benchmark levels, but they also point toward a fast decline in the inflation rates. We also note that in the second half of the sample period many countries have insignificant trend coefficients, implying that the downward movement of their inflation halts. A more careful inspection of the countries which do not display any positive coefficients shows mean values that are also not significantly different than zero, with the exception of Estonia. These results imply that countries that decrease their inflation to EU levels stop monetary tightening and maintain low inflation levels comparable to those of the EU15. In summary, our results indicate that inflation convergence is a feature of the present development of the EU. These findings on inflation convergence are also consistent with recent studies (e.g., Kočenda, 2001; Kutan and Yigit, 2004, 2005; Brada et al., 2005).

The process of inflation convergence should be confronted with disinflation strategies in several new member states that adopted distinct forms of inflation targeting. ${ }^{15}$ The problem lies in the fact that the combination of convergence criteria creates a constraint affecting the compatibility of inflation targeting with the exchange rate convergence criterion embodied in the ERM2 arrangement. Arguments on this issue were voiced from various angles by Natalucci and Ravenna (2002), Buiter (2004), and de Grauwe and Schnabl (2004), among others. New EU members who currently operate under flexible exchange rate regimes and pursue inflation targeting may be confronted with an unpleasant policy shift in favor of exchange rate targeting when entering ERM2. When leaving ERM2, the reverse shift towards an inflation-targeting-like regime under the euro is an imperative. This double shift may be avoided at some cost. However,

\footnotetext{
${ }^{15}$ Orlowski (2001) proposed a sequence of monetary convergence to the Eurozone, based on autonomous monetary policy rather than on an early application of the euro peg. The gradual adjustment process begins with a relatively strict variant of inflation targeting, followed by flexible inflation targeting, and ends with exchange rate targeting. Orlowski (2004) proposed the adoption of money growth rules as indicator variables of monetary policies by the countries converging to a common currency system, in particular by the Eurozone candidate countries. The analytical framework assumes an inflation target as the ultimate policy goal. The converging countries act in essence as "takers" of the inflation target (the Eurozone's inflation forecast). The feasibility of adopting money growth rules depends on stable relationships between money and target variables, which are low inflation and a stable exchange rate.
} 


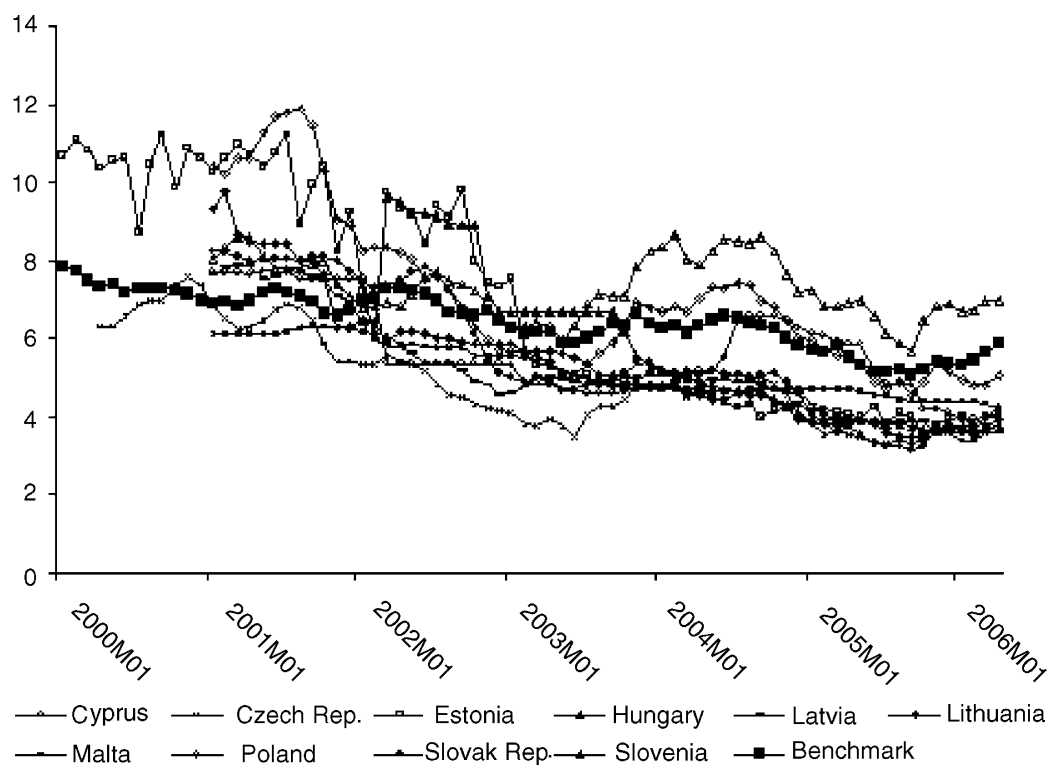

Fig. 4. Interest rate convergence to benchmark.

the viability of such conduct is underlined by specific conditions. ${ }^{16}$ Jonáš and Mishkin (2005) address the future perspective of monetary policy in the transition economies and conclude that even after EU accession, inflation targeting can remain the main pillar of monetary strategy during the time before the Czech Republic, Hungary and Poland join the EMU. Our results indicate that satisfying the inflation criterion should not pose a problem for the majority of new EU member states. ${ }^{17}$ The reality of potential dual-targeting or the need for policy shifts in the future remain open questions.

As mentioned earlier, due to the lack of adequate data in the new EU countries, we are not able to perform an analysis with respect to the interest rate criterion. ${ }^{18}$ Fig. 4 illustrates the general trend calculated based on the government bond yield data. It reveals varying convergence towards the required benchmark, the long-term interest rate in the three lowest inflation countries plus 2\%. While countries like the Czech Republic, Latvia and Malta come close to meeting the interest rate criterion, countries such as Estonia, Hungary and Poland show slower progress. Actually, since 2002 the interest rates have been declining further in most of the countries, reflecting lower inflation, except Hungary and Poland, where the inflation rate has recently been picking up.

\footnotetext{
${ }^{16}$ A dual targeting strategy assumes entering the ERM2 at a central parity close to equilibrium level only for the shortest possible period. The country should have low inflation (and subdued pressures), sustainable external balance, sound fiscal policy and a credible program for long-term fiscal consolidation as the most important characteristics. For more details see Frait (2004).

${ }^{17}$ On other hand, the recent increase in inflation in Lithuania has provoked the IMF to urge that prompt efforts are needed to "insure" against a possible breach of the Maastricht inflation limit.

${ }^{18}$ With the exception of the Czech Republic and Slovenia, 2001 is the first year for which data are available on the reference long-term interest rate. For the Czech Republic, data are available from April 2000, and for Slovenia from March 2002 (ECB, 2004).
} 


\section{Conclusion and policy implications}

We have examined real and nominal convergence of the recent EU member states towards EU standards. Compared to earlier studies, our study provides a more comprehensive look at the convergence performance and prospects of the new members, not only because it combines real and nominal convergence, but also because it uses vastly flexible tests of convergence, allowing for structural breaks and hence providing improved inferences. Instead of using industrial production as a measure of real convergence, we employ data on real percapita GDP. We also measure real convergence using not only local currencies but also euros to capture the impact of euro-area aggregate demand changes and to make inferences about exchange rate convergence.

Results regarding the real convergence show that the Baltic countries are progressing quite a bit faster both in euros and local currency to the EU standards than the other new member states, suggesting that exchange rate convergence is achieved for the Baltic countries, while the currencies of the other currencies have not been as stable against the euro. Hence, the Baltic countries seem to be ready to peg their currencies officially to the euro.

Despite the observed widening of the gap between per-capita GDP levels in euros, closer inspection of the growth rates show that the faster growth rate of the new members will help narrow this gap, leading to the "catching-up" of new members in the next few decades. Especially the stronger growth rates after the beginning of the accession talks (post-break) are indicative of the benefits of the membership prospects or the membership itself, strengthening convergence to the Union. The outcome of the tests, examining per-capita real GDP in local currencies, confirms convergence projections with respect to the core as well as to the periphery. Especially, the results of the post-break period indicate that the introduction of the euro has increased the real per-capita convergence process. However, our finding of slow but steady percapita convergence towards the EU standards suggests that it will take several decades for the convergence to be fully completed. Policymakers can shorten this process by designing further structural reforms and encouraging more FDI and trade flows into the new members.

Results on inflation and interest rates show the significant success of the new members in achieving the criteria set by the Maastricht Treaty, as well as progress towards the ECB's interpretation of price stability. In conclusion, our results indicate that the new EU members have achieved significant nominal convergence and are making steady progress towards real convergence. From the perspective of the EMU membership our findings support frequent arguments that it is the fiscal part of the Maastricht criteria that matters most.

\section{Acknowledgements}

We thank two anonymous referees, Ian Babetskii, John Bonin, Josef Brada, Balázs Égert, Jan Frait, Jan Hanousek, Tomáš Holub, Iikka Korhonen, Srobona Mitra, and Selin Sayek for useful comments and suggestions. We have benefited from presentations at ROSES (Paris I Sorbonne), the DG EcFin Conference (Brussels), LACEA 2005 (Paris) and AEA/ACES 2006 Annual Meetings (Boston).

\section{References}

Andrews, D.W.K., Ploberger, W., 1994. Optimal tests when a nuisance parameter is present only under the alternative. Econometrica 62, 1383-1414. 
Babetskii, I., Boone, L., Maurel, M., 2004. Exchange rate regimes and shocks asymmetry: the case of the accession countries. J. Comp. Econ. 32, 212-229.

Backé, P., Fidrmuc, J., Reininger, T., Schardax, F., 2003. Price dynamics in Central and Eastern European EU accession countries. Emerg. Markets Finance and Trade 39, 42-78.

Bayoumi, T., Eichengreen, B., 1993. Shocking aspects of European monetary integration. In: Torres, F., Giavazzi, F. (Eds.), Growth and Adjustment in the European Monetary Union. Cambridge University Press, Oxford, pp. $193-229$.

Bernard, A.B., Durlauf, S.N., 1996. Interpreting tests of the convergence hypothesis. J. Econ. 71, 161-173.

Boone, L., Maurel, M., 1998. Economic convergence of the CEECs with the EU. CEPR Discussion Paper 2018, London.

Boone, L. Maurel, M., 1999. An optimal currency area perspective of the EU enlargement to the CEECs. CEPR Discussion Paper 2119, London.

Brada, J.C., Kutan, A.M., 2001. The convergence of monetary policy between candidate countries and the European Union. Econ. Sys. 25, 215-231.

Brada, J.C., Kutan, A.M., Zhou, S., 2005. Real and monetary convergence between the European Union's core and recent member countries: a rolling cointegration approach. J. Banking and Finance 29, 249-270.

Buiter, W.H., 2004. The purgatory and beyond: when and how should the accession countries from Central and Eastern Europe become full members of EMU? CEPR Discussion Paper 4342, London.

Buiter, W.H., Grafe, C., 2002. Anchor, float or abandon ship: exchange rate regimes for accession countries. CEPR Discussion Paper 3184, London.

Carlino, G.A., Mills, L.O., 1993. Are US regional incomes converging? J. Monetary Econ. 32, 335-346.

de Grauwe, P., Schnabl, G., 2004. EMU entry strategies for the new member states. Intereconomics 39, $241-247$.

de la Fuente, A., 2002. On the sources of convergence: a close look at the Spanish regions. Eur. Econ. Rev. 46, 569-599.

Dibooglu, S., Kutan, A.M., 2001. Sources of real exchange rate fluctuations in transition economies: the case of Poland and Hungary. J. Comp. Econ. 29, 257-275.

ECB, 2004. European Central Bank convergence report 2004. Frankfurt am Main.

Égert, B., Drine, I., Lommatzsch, K., Rault, C., 2003. The Balassa-Samuelson effect in Central and Eastern Europe: myth or reality? J. Comp. Econ. 31, 552-572.

Fidrmuc, J., Tichit, A., 2004. Mind the break! Accounting for changing patterns of growth during transition. William Davidson Institute Working Paper 643, Ann Arbor, MI.

Fidrmuc, J., Korhonen, I., 2004a. A meta-analysis of business cycle correlation between the Euro area and CEECs: what do we know - and who cares? BOFIT Discussion Papers 20, Helsinki.

Fidrmuc, J., Korhonen, I., 2004b. The Euro goes east: implications of the 2000-2002 economic slowdown for synchronisation of business cycles between the Euro area and CEEs. Comp. Econ. Stud. 46, 45-62.

Fischer, S., Sahay, R., Vegh, C.A., 1998. How far is Eastern Europe from Brussels? IMF Working Paper 53, Washington, DC.

Frait, J., 2004. The convergence criteria - How tight a constraint under inflation targeting? The Czech National Bank, Prague (mimeo). Available at: http://www.cnb.cz/pdf/Jan\%20Frait_MP_under_ERM2.pdf.

Horvath, J., 2003. Optimum currency area theory: a selective review. BOFIT Discussion Paper 15/2003, Helsinki.

Horvath, J., Rátfai, A., 2004. Supply and demand shocks in accession countries to the economic and monetary union. J. Comp. Econ. 32, 202-211.

Janáčková, S., 2000. Price convergence and the readiness of the Czech economy for accession to the European Union. East. Eur. Econ. 38, 73-91.

Jonáš, J., Mishkin, F.S., 2005. Inflation targeting in transition countries: experience and prospects. NBER working paper 9667, Cambridge, MA.

Kočenda, E., 2001. Macroeconomic convergence in transition economies. J. Comp. Econ. 29, 1-23.

Kočenda, E., 2005. Beware of breaks in exchange rates: evidence from European transition countries. Econ. Sys. 29, 307324.

Korhonen, I., Fidrmuc, J., 2001. Similarity of supply and demand shocks between the Euro area and the accession countries. Focus on Transition 2, 26-42.

Kutan, A.M., Yigit, T., 2004. Nominal and real stochastic convergence of transition economies. J. Comp. Econ. 32, 23-36.

Kutan, A.M., Yigit, T., 2005. Nominal and real stochastic convergence: are the new EU members ready to join the Euro zone? J. Comp. Econ. 33, 387-400.

Maddison, A., 1991. Dynamic Forces in Capitalist Development. Oxford University Press, Oxford.

McKinnon, R.I., 1999. Toward virtual exchange-rate stability in Western and Eastern Europe with the advent of EMU. In: Blejer, M.I., Skreb, M. (Eds.), Balance of Payments, Exchange Rates, and Competitiveness in Transition Economies. Kluwer, Boston, pp. 131-158. 
Mishkin, F.S., 2004. Can inflation targeting work in emerging market countries? NBER Working Paper 10646, Cambridge, MA.

Natalucci, F.M, Ravenna, F., 2002. The road to adopting the Euro: monetary policy and exchange rate regimes in EU candidate countries. Board of Governors of the Federal Reserve System International Finance Discussion Paper 741, Washington, DC.

Orlowski, L.T., 2001. From inflation targeting to the Euro-peg: a model of monetary convergence for transition economies. Econ. Sys. 25, 233-251.

Orlowski, L.T., 2004. Money rules for the Eurozone candidate countries. Center for European Integration Studies Working Paper B04-2004, Bonn.

Park, J.Y., Choi, B., 1988. A new approach to testing for a unit root. CAE Working Paper 88-23, Cornell University, Ithaca, NY.

Quah, D.T., 1996. Empirics for economic growth and convergence. Eur. Econ. Rev. 40, 1353-1375.

Richards, A.J., Tersman, G.H.R., 1996. Growth, nontradables, and price convergence in the Baltics. J. Comp. Econ. 23, 121-145.

Salvatore, D., 2004. Restructuring and Euroization in accession countries. J. Policy Model. 26, 889-902.

Sayek, S., Selover, D.D., 2002. International interdependence and business cycles transmission between Turkey and the European Union. South. Econ. J. 69, 206-238.

Taylor, A.M., 1999. Sources of convergence in the late nineteenth century. Eur. Econ. Rev. 43, 1621-1645.

The Treaty, 1999. The Rome, Maastricht and Amsterdam treaties: The Treaty on European Union (the Treaty of Rome) and the Treaty establishing the European Community (the Treaty of Maastricht), amended by the Treaty of Amsterdam: Comparative texts. Euroconfidentiel, Genval.

Tomljanovich, M., Vogelsang, T.J., 2002. Are US regional incomes converging? Using new econometric methods to examine old issues. Empirical Econ. 27, 49-62.

Vogelsang, T.J., 1998. Trend function hypothesis testing in the presence of serial correlation. Econometrica 66, $123-148$. Vogelsang, T.J., 1999. Testing for a shift in trend when serial correlation is of unknown form. Tinbergen Institute Discussion Paper 99-016/4, Amsterdam (last version: Cornell Department of Economics mimeo, 2001).

von Hagen, J., Hofmann, B., 2004. Macroeconomic implications of low inflation in the Euro area. North Am. J. Econ. Finance 15, 5-23. 